\title{
Capital Structure Theories in Finance Research: A Historical Review
}

\author{
Lutfa T Ferdous \\ La Trobe University \\ Bundoora Vic-3083 \\ Australia \\ Email: 1.ferdous@latrobe.edu.au
}

\begin{abstract}
Capital structure in one of the most converse and vital issues in the finance literature. This theoretical review of capital structure provides a synthesis of the theory utilised in capital structure literature. This theoretical review explains two categories of theories that examine the optimum capital structure of a firm. Functional market theories, which propose firms conduct share transaction without being used transaction costs and ii) costly transaction theories. The first group consists of the original capital structure theories of Modigliani and Miller (1958, 1963), Miller (1977), and De Angelo and Masulis (1980). The second range of theories captures the various effects of costly capital market transactions: Pecking Order Theory" accredited to Donaldson (1961); the debt capacity theories that depend on bankruptcy to limit a firm's use of debt financing (Robicheck and Myers, 1966) the agency models developed by Jensen and Meckling (1976), Myers (1977), Smith and Warner (1979); and signalling model by Ross (1977). Recent capital structure literature explored into an analytical structure building up the major contributions starting with the development of agency and bankruptcy theory. These theories are connected with the outcome from financing choices to real debt-equity decisions. Finally, we finish our review with established studies that explore the significances of leverage- equity relationship, as well as its determinants.
\end{abstract}

Keywords: Capital Structure, Theories in Finance, Agency Theory.

\section{Introduction}

Capital Structure is a mix of debt and equity capital maintained by a firm. Capital structure is also referred to as the financial structure of a firm. The capital structure of a firm is very important since it related to the ability of the firm to meet the needs of its stakeholders. Capital structure is a topic that continues to keep researchers pondering. Researchers continue to analyse capital structures and intend to determine whether optimal capital structures exist. An optimal capital structure is usually defined as one that will minimize a firm's cost of capital while maximizing firm value. Hence, capital structure decisions have a great impact on the success of the firm. Exactly how firms choose the amount of debt and equity in their capital structures remains an enigma. Are firms mostly influenced by the traditional capital structures of their industries or are there other reasons behind their actions? The answers to these questions are very important because the actions managers take will affect the performance of the firm, as well as influence how investors will perceive the firm. Modigliani and Miller (1958) are the first ones to landmark the topic structure and the capital structure is irrelevant in determining the firm's value and its future performance. Much emphasis has been placed on releasing the assumptions made by MM, in particular by taking into account corporate taxes (Modigliani and Miller, 1963), personal taxes (Miller, 1977), bankruptcy costs (Stiglitz, 1972; Titman, 1984), agency costs (Jensen and Meckling, 1976; Myers, 1977), and informational asymmetries (Myers,1984). The development of agency theory in the 1980s is coupled with detailed research into the extent and effect of bankruptcy costs during the 1980s, lead to a detailed view of the usefulness of the basic Modigliani and Miller's capital structure theory. Various new managerial theories of the firm (e.g. Jensen and Meckling, 1976; Myers, 1977 and Amihud and Lev, 1981) have been evolved in the context of agency theory and two related problems: agency problem and information asymmetry have received increasing attention in Finance. Two other main theories dominate the capital structure debate: the trade-off theory (TOT) and the pecking order theory (POT). On the other hand, Lubatkin and Chatterjee (1994) prove that there exists a relationship between capital structure and firm value. In more recent literature, authors have shown that they are less interested in how capital structure affects the firm value. Instead, they place more emphasis on how capital structure impacts on the ownership/governance structure thereby influencing top management of the firms to make strategic decisions (Hitt, Hoskissonand Harrison, 1991). These decisions will in turn impact on the overall performance of the firm (Jensen, 1986). Nowadays, the main issue for 
the capital structure is how to resolve the conflict on the firms' resources between managers and owners (Jensen, 1976). Many of these theories have also been empirically tested. To my knowledge, no review has been conducted on the ground of capital structure theories used in determining the optimum capital structure.

\section{Theoretical Review on Capital Structure}

Developments of theory in capital structure can be categorized broadly into two groups:

i) Functional market theories, which assume that individuals and firms can buy and sell securities without incurring transaction costs and ii) costly transaction theories. The first group consists of the original capital structure theories of Modigliani and Miller (1958, 1963), Miller (1977), and DeAngelo and Masulis (1980). The second group includes a range of theories that discuss the various effects of costly capital market transactions. It includes the pure transaction costs or "Pecking Order Theory" accredited to Donaldson (1961); the debt capacity theories that depend on bankruptcy to limit a firm's use of debt financing (Robicheck and Myers, 1966), the agency models developed by Jensen and Meckling (1976), Myers (1977), Smith and Warner (1979); and signalling model by Ross (1977). Recent work in capital structure has expanded into a lucid analytical structure building up the major contributions starting with the development of agency and bankruptcy theory.

Many of these theories have also been empirically tested. Yet there is little consensus on how firms choose their capital structure and much remains to understand the link between theory and practice of capital structure.

"There is no universal theory of capital structure and no reason to expect one.” (Myers, 2003)

This review paper discuss about capital structure theories those provide overview of the optimal choices of financing of a firm: equity and debt. As it is stated that economic theory does not propose any guidelines about financing choices. The answer to the question "How do firms choose their capital structures?" is thus still "We don't know." (Myers, 1984). Though there are other significant conditional theories which propose distinct approach to the "capital structure puzzle" and endeavour to lessen the puzzle from economic status. Discussed theories from the review paper open an arena where researcher can get a historical review of conditional theories which assist to apply the contributing factors of capital structure and effect on firm value. This historical review will be discuss The propositions of Miler and Modigliani, the trade-off, signalling, pecking order and agency theory (including the free cash flow type of research)

\subsection{Miller and Modigliani Propositions}

\section{Capital Structure Theory of Modigliani and Miller, 1958}

The Modigliani and Miller theorem is a financial theory stating that the market value of a firm is determined by its earning power and the risk of its underlying assets, and is independent of the way it chooses to finance its investments or distribute dividends. In the Modigliani -Miller's (1958) article developed within the framework of perfect capital market which characterized by free of taxes, transaction costs, and other frictions; the choice of a firm's capital structure could not affect its market value - because investors could make or unmake any level of homemade leverage they desired by borrowing or lending on personal account. The " $\mathrm{M}$ and $\mathrm{M}$ Capital structure irrelevance proposition" states the circumstances under which capital structure does not influence firm value.

The Assumptions of the theory are - MM employed the concept of arbitrage to develop their theory. Here are the initial MM assumptions-

- There are no personal or corporate taxes.

- Business risk can be measured by EBIT and firms with the same degree of business risk are said to be in a homogeneous risk class.

- All present and prospective investors have identical estimates of each firm's future EBIT, that is, investors have homogenous expectations about expected future corporate earnings and the silkiness of those earnings,

- Stocks and bonds are traded in perfect capital markets. This assumption implies, among other things, (a) that there are no brokerage costs and (b) that investors (both individuals and institutions) can borrow at the same rate as corporations.

- The debt of firms and investors is riskless, so the interest rate on all debt is the risk-free rate. Further, this situation holds regardless of how much debt a firm uses. 
- All cash flows are perpetuities; that is, all firms except zero growth, hence have an "exceptionally constant" EBIT, and all bonds are perpetuities.

MM without Taxes- MM first analysed leverage under the assumption that there are no corporate or personal income taxes. On the basis of their assumptions, they stated and algebraically proved two propositions.

Proposition I - the value of is established by capitalizing its expected net operating income (EBIT) at a constant rate, which is based on the firm's risk class. Under the MM model when there are no taxes, the value of the firm is independent of its leverage. The model implies that,

- The weighted average cost of capital to the firm is completely independent of its capital structure.

- The WACC for the firm, regardless of the amount of debt it uses, is equal to the cost of equity it would have if it used no debt.

Proposition II -the cost of equity to a levered firm is equal to i) the cost of equity to an unlevelled firm in the same risk class plus ii) a risk premium whose size depends on both the differential between a non-levered firm 's costs of debt and equity and the amount of debt used. This proposition shows that the firm's use of debt increases, its cost of equity also raises, and in a mathematically precise manner.

The two propositions imply that the inclusion of more debt in the capital structure will not increase the value of the firm because the benefits of the cheaper debt will be exactly offset by an increase in the riskiness, hence in the cost, of its equity. Thus MM argue that a world without taxes, both value of a firm and its WACC would be unaffected by its capital structure.

\section{Capital Structure Theory of Modigliani and Miller 1963}

In 1963, Modigliani and Miller published a second article that incorporated corporate taxes. With corporate income taxes, they concluded that leverage will increase a firm's value. This occurs because interest is a tax-deductible expense: hence more of a leveraged firm's operating income flows through to investors. Here are the MM propositions when corporations are subject to income taxes but there no personal taxes:

Proposition I - the value of a levered firm is equal to the value of an unlevered firm in the same risk class plus the gain from leverage, The gain from leverage is the value of tax savings, found as the product of corporate tax rate times the amount of debt the firm uses.

The important point here is that when corporate taxes are introduced, the value of the levered firm exceeds that of the non-levered firm by the amount TD. Since the gain from leverage increases as debt increases, in theory, a firm's value is maximized at 100 per cent debt financing.

Proposition II - the cost of equity to levered firm is equal to i) the cost of equity to an unlevered firm in the same risk class plus ii) a risk premium whose size depends on the differential between the costs of equity and debt to an unlevered firm, the amount of financial leverage used, and the corporate tax rate. This proposition II, coupled with the fact that taxes reduce the effective cost of debt, is what produces the proposition I result, namely, that the firm's value increases as its leverage increases.

\section{Capital Structure Theory of Miller 1977}

Although MM included corporate taxes in the second version of their model but didn't extend the model to include personal taxes. However, Merton Miller introduced a model designed to show how leverage affects firms' values when both personal and corporate taxes are taken into account. Miller's model begins with the corporate tax rate, the personal tax rate on income from stocks and the personal tax rate on income from debt. It is to note that stocks' returns come partly as the dividends and partly as capital gains, so weighted average of the effective tax rates on dividends and capital gains, while essentially all debt income comes from interest, which is effectively taxed at investors' top rates.

The Miller Model - the model provides an estimate of the value of a levered firm in a world with both corporate and personal taxes. Miller argued that firms in the aggregate would issue a mix debt and equity securities such that the before-tax yields on corporate securities and the personal tax rates of the investors who bought these securities would adjust until an equilibrium was reached. 


\subsection{Agency Theory}

Before agency theory, previously theorist proposed model assume that the interests of managers and shareholders are effortlessly associated. Though, Adam Smith (1776) prescribe that management and ownership are differed in their own interest conflict.

"The directors of such [joint-stock] companies, however, being the managers rather of other people's money than of their own, cannot well be expected, that they should watch over it with the same anxious vigilance with which the partners in a private co-partner frequently watch over their own. Like the stewards of a rich man. They are apt to consider attention to small matters as not for their master's honour, and very easily give themselves a dispensation from having it. Negligence and profusion, therefore, must always prevail. More or less, in the management of the affairs of such a company." Adam Smith (1776) as quoted in Jensen and Meckling (1976).

Jensen and Meckling in 1976 suggest the conflicting interest of principals (shareholders) and their agents (managers)into their seminar agency theory based paper. Agency cost such as bonding expenditure, monitoring cost and residual loss have arisen from this inconsistent relationship between shareholder and manager and this relationship assist to suggest how the mix of equity and debt can be determined optimum capital structure. Nevertheless, this theory had been comprehended by other authors. Later, Myers (1977) contributed to agency costs of debtand Jensen (1986) explained with the free cash flow.

From the concept agency cost defines two categories of conflict: agency costs of equity and agency costs of debt. Agency cost defines conflicts between managers and shareholders and debt holders and equity holder's conflicts suggest agency costs of debt. I will explain more details about agency cost of equity what impact of debt on the agency costs that ascend from these relationships.

\section{2 (a) Agency Costs of Equity- Benefits of Debt Financing}

Agency costs of outside equity can be demonstrated by comparing the behaviour of a manager when he owns I00 per cent of the residual claims on a company with his behaviour when he sells off a portion of those claims to outsiders. If a company is managed by the owner, he will make operating decisions that maximize his utility, i.e. also the value of the company. However, as the owner-manager's fraction of the equity falls. Also, his fractional claim on the outcomes falls. Generating a divergence between his interests and those of the outside shareholders.

When a manager does not control the complete gain from possible value increasing activities, may accept significant cost from the activities. Thus, manager are not attracted to employ more effort into managing resources rather than involve in transfer wealth to their own interest. In some instance, different interest issue managers may incur some loses from perquisites (such as corporate jets, luxurious offices, etc.) though attain a less amount of gain. As a consequences, manager's attitude towards the decrease in value caused rather than value increase which is called agency cost of equity

Value maximising inefficiency can be lessen significant amount when ownership owned by managers. In this case, when manager absolute shareholding and investment increases, also increases perfectly leveraged firm, manager's shareholding and eliminates the damage from the conflict between the manager and shareholder (Harris and Raviv, 1991).

From agency theory proposition, explained by Jensen and Meckling declare (1976) state that owner will accept complete wealth properties of the previously discussed agency costs of equity. When minority shareholder realise the conflicted relationship between agency and owner, the share price what they may reimburse for security, it may reveal monitoring cost. Thus, this is also expected that for minority shareholders to disburse more resources in monitoring conflicted attitude through agency conflict. The wealth costs to the owner of gaining more cash from the equity markets rise as his portion of ownership reduces.

Debt financing has contributed to the reducing of .free cash flow as demonstrated by Jensen (1986). In this paper Jensen (1986) explain free cash flow as the excess of that essential to account all projects which creates positive net present values. This hard to encourage managers to distribute this cash to shareholders than invest in below the cost of capital or deteriorating this onto inefficiencies of a firm. By issuing debt capital, managers are attached to pay out future cash flows, and they provide the rights to debtholder a file bankruptcy when they fail to pay interest and principle payments.Hence, debt reduces the agency costs of free cash flow is reduced by debt and the cash allocated for expensing at the option of managers. 
It is important to discuss that monitoring function of leverage is highly significant in firms where produce enormous cash flows with low growth forecasts even more important those organisation may shrink. These firms can invest in unprofitable investment due to negative pressure for wasting cash flows. There are two major contribution what debt financing can have on pushing down agency costs of equity and thus enhance firm's value.

\section{2 (b) Agency Costs of Debt- Benefits of Equity Financing}

When a firm consider to be highly leveraged, and potential financial distress could be occur, there are conflicted association exist between shareholders and debt-holders. In this condition,shareholders are interested to follow opportunistic strategies that lead to suboptimal investment. Negative attitude towardsfirm value is called the agency cost of debt-financing.

Jensen and Meckling(1976) commented especially on highly levered firm and probability of bankruptcy. Highly leveraged firm and close to bankruptcy firm could have incentive on investment onto highly risk related firm, when an investment profits large returns that are well above the face value of the debt, shareholders will awardmajor gain from the investment. On the contrary, when investment become loss, debt-holders will incur the limited liability of the shareholders. Thus, shareholders may enter even for irrationally risky ventures that they wouldn't prefer to invest they are value lessening projects. From Jensen and Meckling(1976) summary, the agency costs associated with debt consist of 1) the opportunity wealth loss caused by the impact of debt on the investment decisions of the company; 2) the monitoring and bonding expenditures by the bondholders and the company; 3) the bankruptcy and reorganization costs.

This kind of investment reduces value of a debt and this loss in value of the equity from the poor investment can be more than offset by the gain in equity value captured at the expense of debt-holdersHarris and Raviv (1991). When a debt-holders perfectly forecast shareholders future attitude during debt issue, shareholders may receive less what they anticipated.

Hence, the cost of the incentive to invest in value-decreasing projects created by a higher proportion of debt in the capital structure is borne by the shareholders who issue debt. This effect called the "asset substitution effect"', is one of the agency costs of debt financing. Another significant agency cost of debt represents the underinvestment problem identified by Myers (1977).

There are three types of agency costs which can help explain the relevance of capital structure.

- When debt-equity increases, management prone to invest risky projects (even consider negative NPV project). As project is successful, shareholders achieve upside gain, otherwise when project downside they receive downside payments. When the projects are undertaken, there is a chance of firm value decreasing and a wealth transfer from debt holders to shareholders.

- Underinvestment problem: When debt is risky especially growth company, debtholders accumulate more gain than shareholders. Thus, management has an incentive to reject positive NPV projects, even though they have the potential to increase firm value.

Myers (1977) state that probability of bankruptcy company frequently invest new capital oriented project as they think it could assist bondholders at their expense, even capital may invest may bring value-increasing projects. The reason behind that shareholders may consume full cost of investment, though investment returns would be gain majority by the debt holders.

- Free cash flow: unless free cash flow is given back to investors, management has perks etc. Increasing leverage imposes financial discipline on management.

\subsection{Trade off Theory}

The Trade-Off Theory of capital structure is a theory in the kingdom of Financial Economics about the corporate finance choices of corporations. Its purpose is to explain the fact that firms or corporations usually are financed partly with debt and partly with equity use by balancing the costs and benefits.

Financing with debt has some tax benefit, there are some financing cost also coming with debt. There are financial distress cost such as bankruptcy costs of debt and non-bankruptcy costs. The marginal benefit of debt enhance as well as marginal cost increases in this case a firm enhancing its overall value will focus on this trade-off when choosing how much debt and equity to use for financing. Although other substitute theories empirical evidence are 
not clear, the significance of this theory has often been questioned. Other theorist have recommended it is the mechanical change in asset prices that make up for most of the variation in capital structure.

The conventional sort of the research of Kraus and Litzenberger (1973) who measured a balance between the deadweight costs of bankruptcy and the tax saving benefits of debt, agency costs are also included in the balance. This theory is considered as a competitor theory to the Pecking Order Theory of Capital Structure.

As the Debt equity ratio (i.e. leverage) increases, there is a trade-off between the interest tax shield and bankruptcy, causing an optimum capital structure, D/E*

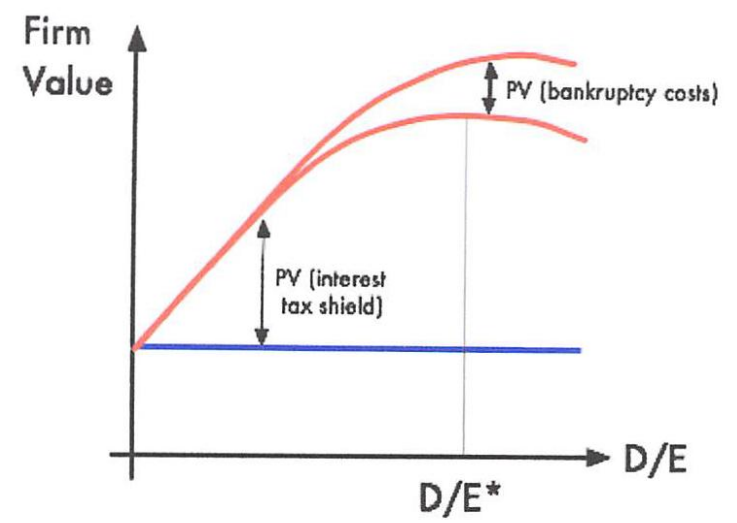

Figure 1: Trade-off Theory graphical representation

The assumptions of the theory are i) Taxes do exist ii) Capital markets are not perfect and iii) Costs of bankruptcy and costs of financial distress exist. The tax considerations for this theory are-

- Interest is tax deductible and, therefore, creates an interest tax subsidy. The greater the firm's marginal tax rate the greater the value of the interest tax shield.

- The value of the interest tax subsidy depends on the firm's ability to generate taxable income.

- The more a firm borrows the less the expected realized value of the interest tax shield.

- Given that there are other ways to shield income from taxes, the greater these alternative tax reducing opportunities the lower the value of the interest tax shield.

- Equity investors have a tax advantage relative to debt investors, which offset the tax advantage of debt at the corporate level.

Myers (1977) concludes that there is a moderate tax advantage to debt if you can use the tax shields. It is to note that taxes cannot be the only factor because we do not see firms with $100 \%$ debt. Costs of Bankruptcy are the loss of value of the assets when sold under the pressures of bankruptcy (not the loss in value prior to filing but the loss caused by liquidating).

Costs of Bankruptcy $=\mathrm{f}$ (Intangible Assets to Total Assets)

Intangible assets are not easily transferable and, therefore, their value will decrease dramatically if bankruptcy occurs. Costs of Financial Distress are the losses associated with decisions that are caused by a firm being in financial distress (Lucent Technology).

Costs of Financial Distress $=\mathrm{f}$ (Intangible Assets to Total Assets)

- The defection of key employees, customers, and suppliers

- The underinvestment problem or a decrease in new positive NPV investments (internal sources and external sources dry up)

- The opportunity costs associated with managing the crisis

All of these costs are higher for firms with intangible assets (tech/high growth stocks) and, therefore, these firms should avoid the possibility of financial distress. Again, think not just of the probability of financial distress but the value lost if distress occurs. 
The Trade-off Theory predicts that an optimal capital structure does exist and is found as the optimal trade-off between the tax benefits of debt and the increase in the costs of financial distress associated with debt. $\mathrm{V}($ firm $)=\mathrm{PV}($ operating cash flows $)+\mathrm{PV}($ interest-tax shield $)-\mathrm{PV}($ Costs of Financial Distress $)$

There are some empirical evidence that consistent with Trade-off Theory, it focuses that varying debt levels across industries but similar debt levels within industries and characteristics of LBO candidates. Again, inconsistent with Trade-off Theory shows that $\mathrm{D} / \mathrm{A}=\mathrm{f}$ (profitability), foreign countries with no tax shield have debt, stock market reaction to capital structure changes - i) equity offerings cause a decrease in value, ii) debt offerings cause no change in value, iii) debt for equity swaps cause an increase in value, iv) equity for debt swaps cause a decrease in value and v) equity repurchases cause an increase in value Implications of the Trade-Off Models - the trade-off models cannot be used to specify a precise optimal capital structure. According to the models, each firm should set its target capital structure such that the costs and benefits of leverage are balanced at the margin because such a structure will maximize its value. The empirical support for the trade-off models is rather weak, which suggests that factors not incorporated into these models are also at work.

\subsection{Bankruptcy Theory}

In principle a firm becomes bankrupt when the value of its assets equals the value of its debt. So the value of equity is zero and the stockholders turn over control of the firm to the bondholders. At this time, the bondholders hold assets whose value is exactly equal to what is owed on the debt. In a perfect world, there are no costs associated with the transfer of ownership, and the bondholders do not lose anything. The costs associated with bankruptcy may eventually offset the tax-related gains from leverage.

Direct Bankruptcy Costs - when the value of a firm's assets equals the value of its debt, then the firm is economically bankrupt in the sense that the equity has no value. However, the formal turning over of the assets to the bondholders is a legal process, not an economic one. There are legal and administrative costs to bankruptcy. Because of expenses associated with bankruptcy, bondholders won't get all that they are owned. The legal and administrative expenses associated with the bankruptcy proceeding are the direct bankruptcy costs.

Indirect Bankruptcy Costs - because it is expensive to go bankrupt, a firm will spend resources to avoid doing so. A firm is having significant problems in meeting debt obligations, it is experiencing financial distress. The costs of avoiding a bankruptcy filing -incurred by a financially distressed firm are called indirect bankruptcy costs.

Bankruptcy Process - One of the consequences of using debt is the possibility of financial distress, which can be defined in several ways:

- Business failure - the term is usually used to refer to a situation in which a business has terminated with a loss to creditors, but even an all-equity firm can fail.

- Legal Bankruptcy - firms or creditors bring petitions to an authorized court for bankruptcy. Bankruptcy is a legal proceeding for liquidating or reorganizing a business.

- Technical Insolvency - it occurs when a firm is unable to meet its financial obligations.

- Accounting Insolvency - firms with negative net worth are insolvent on the books. This happens when the total book liabilities exceed the book value of the total assets.

Finance theorists have long realized that sufficiently large costs of bankruptcy and financing distress could dramatically reduce the incentive for firms to use debt financing, even in the world of otherwise perfect capital markets. Moreover, in the real world of finance, it reveals the literature suggests that a bankrupt company's security holders and protected bondholders frequently lose their entire investment in a firm. If bankruptcy costs are material, the advantage may become offset at some level of debt. Then a higher risk of bankruptcy should reduce the attractiveness of debt, and optimal capital structure with a high bankruptcy rank should contain low amounts of debt. Agency literature suggests that potential bankruptcy costs are part of the agency-debt costs.

\subsection{Pecking Order theory}

Pecking Order theory suggest the cost of asymmetric information. This theory suggest that firms highlighted the internal financing to equity as internal debt is used first, and when that is depleted debt is issued, and when it is not sensible to issue any more debt, equity is issued. This theory reserves that a firm follows financing sources and 
provide importance internal financing and prefers debt over equity when external financing is available.

Pecking order theory is promoted by Myers (1984) and argued that equity capital is less preferred which mean it is important to raise capital when manager who informed better about the firm capital condition issues new equity capital, investors believe that managers suggest that the firm is overvalued and managers are taking opportunities of this over-valuation.

\section{According to the theory of Myers and Majluf, 1984}

External debt financing is better than equity financing and it is good than to invest state securities than risky one. Firms which investment opportunities exceed operating cash flows and the ability to issue less risky debt, it may decline good investments rather than issue risky securities to finance them. In some instances, shareholders may earn more when the firm transfers sufficient financial slack to commence good investment opportunities that may arise. Firms may figure more financial slack by limiting dividends when investment requirements are modest or by issuing stock in periods when managers' information benefit could be small. When a managers could have larger information, and the share is issued to finance investment, the stock price may down, other things equal. This relation of issuance of default-free debt.

\subsection{Arbitrage theory}

Arbitrageur of a capital structure strive for opportunities created by distinction pricing of various instruments issued by corporation. As an example traditional bonds and convertible bonds. Convertible bonds are conditional and contracted which covert shares to equity.

The stock-option constituent of a convertible bond has a calculable value in itself. The value of the whole instrument should be the value of the traditional bonds plus the extra value of the option feature. When the spread, the difference between the convertible and the non-convertible bond s grows excessively, then the capital-structure arbitrageur will be converge.

\section{Conclusion}

The papers in this literature explore factors that suggest organisation target capital structures as well as the degree to which future leverage-equity selections transfer firms back toward their optimal targets to capital structure. Since the influential work of Modigliani and Miller (1958) on the insignificance of capital structure in investment decision, a wealthy theoretical literature has materialized that models firm's capital structure choice under different assumptions. For example, theories such as trade-off theory rely on traditional factors such as tax advantage and potential bankruptcy cost of debt while others use the asymmetric information or game theoretical framework in which debt or equity is used as a signalling mechanism or strategy tool. Many of these theories have also been empirically tested. Yet there is little consensus on how firms choose their capital structure and how the firm-specific factors influence the shape of the capital structure. This research develops a link between theory and practice of capital structure.

References

Amihud, Y., \& Lev, B. (1981). Risk reduction as a managerial motive for conglomerate mergers. The bell journal of economics, 605-617.

Booth, P. J., Tan, S. J., Holm, P., \&Callesen, H. (2001). Application of the zona-free manipulation technique to porcine somatic nuclear transfer. Cloning \& Stem Cells, 3(4),

DeAngelo, H., \&Masulis, R. W. (1980). Optimal capital structure under corporate and personal taxation. Journal of financial economics, 8(1), 3-29.

Donaldson, G. (1961). Corporate Debt Capacity. A study of corporate debt policy and the determination of corporate debt capacity.(Second printing.): Division of Research, Graduate School of Business Administration, Harvard Univ.

Harris, M., \&Raviv, A. (1991). The theory of capital structure. The Journal of Finance, 46(1), $297-355$.

Haugen, R. A., \&Senbet, L. W. (1978). The insignificance of bankruptcy costs to the theory of optimal capital structure. The Journal of Finance, 33(2), 383-393.

Higgins, R. C., \&Schall, L. D. (1975). Corporate bankruptcy and conglomerate merger. The Journal of Finance, 30(1), 93-113.

Hirshleifer, J. (1970). Investment, interest, and capital.

Hitt, M. A., Hoskisson, R. E., \& Harrison, J. S. (1991). Strategic competitiveness in the 1990s: Challenges and 
opportunities for US executives. Academy of Management Perspectives, 5(2), 7-22.

Jensen, M. C. (1986). Agency costs of free cash flow, corporate finance, and takeovers. The American economic review, 76(2), 323-329.

Jensen, M. C., \&Meckling, W. H. (1976). Theory of the firm: Managerial behavior, agency costs and ownership structure. Journal of financial economics, 3(4), 305-360.

Kraus, A., \&Litzenberger, R. H. (1973). A state-preference model of optimal financial leverage. The Journal of Finance, 28(4), 911-922.

Lubatkin, M., \& Chatterjee, S. (1994). Extending modern portfolio theory into the domain of corporate diversification: does it apply? Academy of Management Journal, 37(1), 109-136.

Martin, J. D., Cox, S. H., \&MacMinn, R. D. (1988). The theory of finance: evidence and applications: Harcourt Brace College Publishers.

Miller, M. H. (1977). Debt and taxes. The Journal of Finance, 32(2), 261-275.

Modigliani, F., \& Miller, M. H. (1958). The cost of capital, corporation finance and the theory of investment. The American, 1, 3 .

Modigliani, F., \& Miller, M. H. (1963). Corporate income taxes and the cost of capital: a correction. The American economic review, 433-443.

Myers, S. C. (1977). Determinants of corporate borrowing. Journal of financial economics, 5(2), 147-175.

Myers, S. C. (1984). The capital structure puzzle. The Journal of Finance, 39(3), 574-592.

Myers, S. C. (2003). Financing of corporations. In Handbook of the Economics of Finance (Vol. 1, pp. 215-253): Elsevier.

Myers, S. C., \&Majluf, N. S. (1984). Corporate financing and investment decisions when firms have information that investors do not have. Journal of financial economics, 13(2), 187-221.

Myers, S. C., \& Pogue, G. A. (1974). A programming approach to corporate financial management. The Journal of Finance, 29(2), 579-599.

Ross, S. A. (1977). The determination of financial structure: the incentive-signalling approach. The bell journal of economics, 23-40.

Shleifer, A., \&Vishny, R. W. (1997). A survey of corporate governance. The Journal of Finance, 52(2), 737-783.

Smith, A. (1776). The wealth ofnations. New York: The Modern Library.

Smith Jr, C. W., \& Warner, J. B. (1979). On financial contracting: An analysis of bond covenants. Journal of financial economics, 7(2), 117-161.

Stiglitz, J. E. (1972). Some aspects of the pure theory of corporate finance: bankruptcies and take-overs. The Bell Journal of Economics and Management Science, 458-482.

Titman, S. (1984). The effect of capital structure on a firm's liquidation decision. Journal of financial economics, 13(1), 137-151.

Warner, J. B. (1977). Bankruptcy, absolute priority, and the pricing of risky debt claims. Journal of financial economics, 4(3), 239-276.

\section{Copyrights}

Copyright for this article is retained by the author(s), with first publication rights granted to the journal.

This is an open-access article distributed under the terms and conditions of the Creative Commons Attribution license (http://creativecommons.org/licenses/by/4.0/) 